\title{
COMMENTS
}

\section{Making the Criminal Pay in Cash: The Ex Post Facto Implications of the Mandatory Victims Restitution Act of 1996}

\author{
Irene J. Chase†
}

Perhaps surprisingly, under current federal law a criminal defendant may be sentenced to pay restitution to a victim. This result seems contradictory to the common view that most criminals are indigent. Indeed, one may argue that poverty often provides the impetus for a crime. ${ }^{1}$ Despite this anomaly, Congress incorporated restitution into the criminal system in the 1982 Victim and Witness Protection Act ("VWPA")."

The VWPA, which originally applied to almost all federal crimes, gives the trial judge considerable discretion in determining whether to order restitution, although this discretion is limited by several factors. ${ }^{3}$ Most importantly, in determining whether to order restitution, the court was directed by the statute to consider the ability to pay.

In 1996, Congress enacted a related provision, the Mandatory Victims Restitution Act ("MVRA"). The MVRA replaces portions of the VWPA; however, like the VWPA, it also authorizes courts to issue

$\dagger \quad$ B.A. 1997, University of Virginia; J.D. Candidate 2001, The University of Chicago.

1 See James K. Stewart, The Urban Strangler: How Crime Causes Poverty in the Inner City, 37 Pol Rev 6,6 (Summer 1986) (noting "[t]he idea that poverty causes crime goes back at least as far as Aristotle, who called poverty 'the parent of revolution and crime"'); Charles E. Silberman, Criminal Violence, Criminal Justice 87-116 (Random House 1978) (arguing that poverty is a major cause of crime); Mabel A. Elliott, Crime in Modern Society 385 (Harper \& Brothers 1952) (discussing economic causes of crime).

2 Pub L No 97-291, 96 Stat 1248 (1982), codified at 18 USC \& 3663 (1994 \& Supp 1998).

318 USC $\$ 3663$ (a)(1)(B)(i)(II). The statute lists the following factors to be considered by a court in determining whether to order restitution: "the financial resources of the defendant, the financial needs and earning ability of the defendant and the defendant's dependents, and such other factors as the court deems appropriate." Id.

418 USC \& 3663(a)(1)(B)(i)(II).

5 Pub L No 104-132, 110 Stat 1227 (1996), codified at 18 USC $\S 3663$ A (Supp 1998).

6 When the MVRA was enacted, the VWPA was amended to apply only to those offenses "other than an offense described in [the MVRA]." 18 USC $\$ 3663(a)(1)(A)$. 
restitution orders while sentencing a criminal defendant. The MVRA removes certain crimes from the scope of the VWPA, namely crimes of violence; offenses against property, including any committed by fraud and deceit; and offenses relating to tampering with consumer products. ${ }^{9}$ As the name implies, the MVRA makes a restitution order mandatory for certain crimes and renders the defendant's ability to pay irrelevant in determining the amount of the restitution order." Thus, an indigent defendant whose crime falls under the MVRA will always be ordered to pay restitution while an indigent defendant under the VWPA has only a chance of receiving such an order. This change in the law has been uniformly agreed to constitute an "increase" in punishment, ${ }^{11}$ which invokes the Ex Post Facto Clause."

Congress stated that the MVRA would be effective, "to the extent constitutionally permissible ... for sentencing proceedings in cases in which the defendant is convicted on or after" April 24, 1996. By emphasizing the conviction date, instead of the date of the crime, Congress has forced some courts to tackle the issue of whether application of the MVRA to defendants convicted after April 24, 1996, but who committed the crime before April 24, 1996, violates the Ex Post Facto Clause of the Constitution. ${ }^{14}$

Currently the circuit courts disagree over whether retroactive application of the MVRA violates the Ex Post Facto Clause. Because the Ex Post Facto Clause only applies to criminal penalties, the crucial point of dissension has been whether restitution is a civil or criminal penalty under the MVRA. ${ }^{15}$ If the MVRA is a criminal statute then the Ex Post Facto Clause applies; if the MVRA is a civil statute then the Ex Post Facto Clause does not apply. This classification is signifi-

See 18 USC $\$ \$ 3663,3663 A$

818 USC $\$ 3663(a)(1)(A)$ (stating that the VWPA does not apply to "an offense described in" the MVRA).

$9 \quad 18$ USC $\$ 3663 \mathrm{~A}(\mathrm{c})(1)(\mathrm{A})$.

1018 USC $\$ 3663 \mathrm{~A}$ (not mentioning the defendant's ability to pay).

11 See United States $v$ Newman, 144 F3d 531, 537 n 5 (7th Cir 1998) (noting the change from discretionary to mandatory "constitute[s] an 'increase' in punishment"); United States $v$ Bagget, 125 F3d 1319,1322 (9th Cir 1997) (holding "[t]he MVRA ... caused a substantive change in the VWPA to [defendants'] detriment").

12 See Calder v Bull, 3 US (3 Dallas) 385, 390 (1798) (noting that the Ex Post Facto Clause prohibits the retroactive application of "[e]very law that changes the punishment, and inflicts a greater punishment").

13 Mandatory Victims Restitution Act $\S 211$, codified at 18 USC $\S 2248$ note (Supp 1998) (effective date of 1996 amendments).

14 US Const Art I, § 9, cl 3 ("No Bill of Attainder or ex post facto Law shall be passed.").

15 Compare United States v Williams, 128 F3d 1239, 1241 (8th Cir 1997) ("We conclude an order of restitution under the MVRA is punishment for Ex Post Facto Clause purposes."), with Newman, 144 F3d at 542 ("For all of these reasons, we hold that restitution authorized by the VWPA (and mandatorily imposed under the MVRA) is not a criminal punishment for the purposes of the Ex Post Facto Clause."). 
cant to other constitutional clauses as well, such as the Double Jeopardy Clause, ${ }^{16}$ which only applies to criminal penalties, and the Seventh Amendment right to a jury trial, which only applies to civil cases. ${ }^{17}$

Restitution under the MVRA could reasonably be viewed as either civil or criminal, but courts should interpret restitution as a criminal penalty. The basic tools of statutory construction indicate that both the civil and criminal interpretation of restitution are equally plausible. Construing restitution as a civil penalty, however, implicates serious Seventh Amendment concerns. ${ }^{18}$ Applying the canon of constitutional avoidance, ${ }^{19}$ this Comment argues that restitution should be construed as a criminal penalty under the MVRA to avoid Seventh Amendment concerns. Because restitution under the MVRA should be considered a criminal penalty, retroactive application of the MVRA would violate the Ex Post Facto Clause.

The Comment proceeds as follows. Part I sets forth the Supreme Court's Ex Post Facto Clause jurisprudence with particular focus on the Court's guidelines regarding the civil/criminal distinction. Part II then analyzes the circuit courts' debate over the interplay between the MVRA and the Ex Post Facto Clause. ${ }^{21}$ Part III concludes that courts should interpret restitution under the MVRA as a criminal penalty and declare the Act's retroactive application unconstitutional.

16 US Const Amend V. See Helvering v Mitchell, 303 US 391, 399 (1937) (stating the Double Jeopardy Clause only applies to criminal sanctions). See also United States $v$ Ward, 448 US $242,248(1980)$ (stating that the civil/criminal distinction is important to evaluate Fifth and Sixth Amendment issues).

17 See US Const Amend VII.

18 US Const Amend VII (providing a right to jury "[i]n Suits at common law").

19 See Edward J. DeBartolo Corp v Florida Gulf Coast Bldg \& Constr Trade Council, 485 US 568,575 (1988) ("[W] here an otherwise acceptable construction of a statute would raise serious constitutional problems, the Court will construe the statute to avoid such problems."). See also notes $163-69$ and accompanying text.

20 Although this ex post facto problem will arise less often as time passes, because of the serious lag time of the federal courts, criminals who have committed crimes before April 24, 1996 , will continue to be brought before the courts. In addition, classification of restitution under the MVRA is important because it can affect holdings under constitutional provisions other than the Ex Post Facto Clause.

21 This Comment will only address crimes that were completed before the effective date, April 24, 1996. Continuing offense crimes pose a different question from completed crimes in that they may have started before the effective date but continued beyond such a date. These types of crimes will not be discussed as they involve different issues. See, for example, United States v Futrell, 209 F3d 1286, 1289-90 (11th Cir 2000) (holding the "ongoing nature of the conspiracy enables application of the [MVRA] without violating the Ex Post Facto Clause" despite its precedent that "the MVRA clearly does not apply to a defendant whose criminal conduct occurred and ceased prior to April 24, 1996"). 


\section{The Supreme Court's Ex Post Facto Clause Jurisprudence}

Article I of the United States Constitution expressly states "[n]o .. . ex post facto Law shall be passed." Although the prohibition is explicit, the Constitution offers no additional guidance in determining what constitutes an ex post facto law. Accordingly, courts have assumed the duty of developing standards for analyzing ex post facto issues. The Supreme Court initially examined the scope of the Ex Post Facto Clause in the 1798 case Calder v Bull..$^{23}$ In that case, the Court listed four categories of laws that would violate the Ex Post Facto Clause. ${ }^{24}$ Since Calder, the Court has developed a two-part test for analyzing ex post facto issues. In Weaver $v$ Graham, ${ }^{25}$ the Court stated that "for a criminal or penal law to be ex post facto: it must be retrospective, that is, it must apply to events occurring before its enactment, and it must disadvantage the offender affected by it. ${ }^{26}$ The Court also noted that "no ex post facto violation occurs if the change effected is merely procedural" as opposed to a substantive change."

As the Court alludes in Weaver, ${ }^{28}$ a law must be criminal or penal in order for the Ex Post Facto Clause to apply. ${ }^{29}$ Consequently, before an ex post facto analysis is begun, the Supreme Court has held that a

22 US Const Art I, $\S 9, \mathrm{cl} 3$. See also id $\S 10, \mathrm{cl} 1$ ("No State shall ... pass any ... ex post facto Law.").

233 US ( 3 Dallas) 385 (1798) (finding that the Ex Post Facto Clause does not prohibit every retrospective law).

24 The Court stated:

1st. Every law that makes an action done before the passing of the law, and which was innocent when done, criminal; and punishes such action. 2 d. Every law that aggravates a crime, or makes it greater than it was, when committed. $3 \mathrm{~d}$. Every law that changes the punishment, and inflicts a greater punishment, than the law annexed to the crime, when committed. 4th. Every law that alters the legal rules of evidence, and receives less, or different testimony, than the law required at the time of the commission of the offence, in order to convict the offender.

Id at 390 .

25450 US 24 (1981) (holding that a Florida law that reduced the time deducted from a prison sentence for good behavior could only constitutionally apply to inmates who had committed crimes after the passage of the law).

26 Id at 29.

27 Id at 29 n 12 . See also note 206.

28 Id at 29.

29 See Collins $v$ Youngblood, 497 US 37, 41 (1990) (acknowledging that "[a]lthough the Latin phrase 'ex post facto' literally encompasses any law passed 'after the fact,' it has long been recognized by this Court that the constitutional prohibition on ex post facto laws applies only to penal statutes"); Marcello $v$ Bonds, 349 US 302, 319-20 (1955) ("The Court [ ] has stated over and over again ... that the Ex Post Facto Clause applies only in criminal cases."); Harisiades $v$ Shaughnessy, 342 US 580, 595 (1952) ("The inhibition against the passage of an ex post facto law ... applies only to criminal laws."); Republic Natural Gas Co v Oklahoma, 334 US 62, 90 n 21 (1948) (noting that "ex post facto legislation ... was limited to criminal and penal consequences"). See also Kansas v Hendricks, 521 US 346, 369 (1997) (stating that "an essential prerequisite" for the Ex Post Facto Clause is that the act is punitive). 
court must first determine whether the penalty involved is civil or criminal..$^{30}$ In determining whether a sanction is civil or criminal, the Supreme Court has stressed that the question is first one of statutory construction. ${ }^{31}$ If the legislature has a stated intent, then courts should defer to it. ${ }^{32}$ Thus, the first step in determining whether a law violates the Ex Post Facto Clause is to determine congressional intent by examining the statute. Although a clear intent to treat a penalty as civil is not dispositive, it carries significant weight. ${ }^{33}$ Courts should "reject the legislature's manifest intent only where a party challenging the statute provides 'the clearest proof' that 'the statutory scheme [is] so punitive either in purpose or effect as to negate [the State's] intention' to deem it "civil."

The Supreme Court has identified a number of factors to consider when determining whether a statute is clearly punitive. Although these factors are gleaned from various Supreme Court cases, the Court consolidated them into a single list of seven factors in Kennedy $v$ Mendoza-Martinez. ${ }^{35}$ The factors are:

Whether the sanction involves an affirmative disability or restraint, whether it has historically been regarded as a punishment, whether it comes into play only on a finding of scienter, whether its operation will promote traditional aims of punishment: retribution and deterrence, whether the behavior to which it applies is already a crime, whether an alternative purpose to which it may rationally be connected is assignable to it, and whether it appears excessive in relation to the alternative purpose assigned. ${ }^{36}$

30 Not all of the Supreme Court cases regarding the civil/criminal penalty distinction address the, issue in the ex post facto context. Some involve the Double Jeopardy Clause and the Fifth and Sixth Amendments. However, these cases are applicable to the Ex Post Facto Clause because the Supreme Court has implied that there is not a difference in evaluating the civil/criminal distinction under the various constitutional safeguards. In United States $v$ Ward, 448 US 242, 248 (1980), the Court commented that the distinction between a civil and criminal penalty is important to evaluate both Fifth and Sixth Amendment issues. Later in Hendricks, 521 US at 361 , the Court collapsed its analysis of the civil/criminal distinction under both the double jeopardy and ex post facto claims. Thus, the standard applies in the ex post facto context despite the fact that not all of the cases generating this standard involve the Ex Post Facto Clause.

31 See Hendricks, 521 US at 361 (stating that the "categorization of a particular proceeding as civil or criminal 'is first of all a question of statutory construction'"), quoting Allen v llinois, 478 US 364, 368 (1986); Ward, 448 US at 248 (remarking "[ $t$ ]his Court has often stated that the question whether a particular statutorily defined penalty is civil or criminal is a matter of statutory construction"); Helvering $v$ Mitchell, 303 US 391, 399 (1938) (noting the question of whether the sanction is criminal is "one of statutory construction").

32 Hendricks, 521 US at 361 (stating that "we ordinarily defer to the legislature's stated intent").

33 Id.

34 Id, quoting Ward, 448 US at 248-49.

35372 US 144 (1963).

36 Id at $168-69$. 
The first five factors attempt to determine whether the penalty has criminal characteristics. It may be useful to think of these factors as judging how closely a sanction resembles imprisonment, which is indisputably a criminal sanction. ${ }^{37}$ For example, the first factor asks whether the sanction involves an affirmative disability or restraint, a characteristic that clearly fits imprisonment. The sixth and seventh factors question whether the sanction has civil purposes in addition to the criminal purposes of deterrence and retribution. ${ }^{38}$

Despite setting forth this list, the Court, in Mendoza-Martinez, acknowledged the uncertainty that is inherent in the civil/criminal distinction. ${ }^{39}$ The Court admitted that application of the factors could be "extremely difficult and elusive of solution" and that the factors "may often point in differing directions." ${ }^{40}$ However, the Court has repeatedly relied on these factors in making a civil/criminal distinction." Such a distinction is necessary because of the many constitutional provisions that are triggered by classifying a penalty as criminal. ${ }^{42}$ The current debate $^{43}$ over the retroactive application of the MVRA illustrates both the significance and complexity of the civil/criminal distinction.

\section{MANDATORY VICTIMS RESTITUTION ACT}

\section{A. History of the MVRA}

Congress enacted the Mandatory Victims Restitution Act on April $24,1996,{ }^{44}$ to replace parts of the discretionary restitution provision in the VWPA with a mandatory restitution provision. Some members of Congress, in debating the passage of the MVRA, noted

37 See Austin v United States, 509 US 602, 620 (1993) (mentioning "the traditional criminal sanction [ ] of ... imprisonment"); Flemming v Nestor, 363 US 603, 617 (1960) (noting the "infamous punishment' of imprisonment").

38 See Kelly v Robinson, 479 US 36, 53 (1986) (stating "criminal proceedings focus on the State's interests in rehabilitation and punishment, rather than the victim's desire for compensation").

39372 US at $168-69$.

40 Id

41 See, for example, Hudson v United States, 522 US 93, 99-100 (1997) (noting the Mendoza-Martinez factors "provide useful guideposts"); Hendricks, 521 US at 361-64 (applying the Mendoza-Martinez factors); Ward, 448 US at 249 (stating that while the Mendoza-Martinez factors "certainly [are] neither exhaustive nor dispositive, [they have] proved helpful" in determining whether a penalty was civil or criminal); Bell v Wolfish, 441 US 520,537-38 (1979) (listing the Mendoza-Martinez factors and noting that they "provide useful guideposts").

42 Many of the procedural safeguards in the Constitution are limited to criminal matters. See, for example, the Fifth Amendment's right against self-incrimination, US Const Amend V, and the Eighth Amendment's prohibition against cruel and unusual punishment, US Const Amend VIII. See also notes 16-17 and accompanying text.

43 See note 15.

4418 USC $\$ 3663 \mathrm{~A}$. 
with displeasure the low number of restitution orders being issued under the VWPA. Senator Hatch, a cosponsor of the Bill, stated, "[f]ederal courts ordered restitution in only 20.2 percent of criminal cases," which broke down to "only 27.9 percent of all murders, 28.2 percent of all kidnappings, 55.2 percent of all robberies, and 12.5 percent of all sexual abuse[ ] cases." ${ }^{45}$ He further stated this was "simply not enough." Senator Feinstein complained that "so many people in our society are affected by crime.... And yet, restitution to the victim is infrequently awarded." The Committee Report noted, "As a matter of practice, restitution is infrequently used and indifferently enforced." ${ }^{48}$ By making restitution mandatory for certain crimes, some members of Congress clearly hoped to increase the number of restitution orders.

The MVRA replaces portions of a related law, the VWPA. The VWPA applies only to offenses "other than an offense described in [the MVRA]." The original scope of the VWPA $^{50}$ was extremely broad; it included all offenses under Title 18, the section that details most federal crimes. ${ }^{51}$ The VWPA also gives the trial judge a large amount of discretion, limited only by a few factors, to determine whether an order of restitution should issue. These factors include "the financial resources of the defendant, the financial needs and earning ability of the defendant and the defendant's dependents, and such other factors as the court deems appropriate."

Unlike the VWPA, the MVRA does not apply to every criminal act under Title 18; it applies only to specified offenses: crimes of violence; offenses against property, including those committed by fraud or deceit; and offenses related to tampering with consumer products. However, despite its narrower scope, the MVRA is harsher than the VWPA, because under the MVRA, a judge must order restitution in every circumstance, regardless of the defendant's financial situation. ${ }^{\text {s4 }}$ The judge is stripped of any discretion in making such an order and the defendant's ability to pay becomes irrelevant.

45141 Cong Rec S 19277 (Dec 22, 1995) (statement of Sen Hatch).

46 Id.

47141 Cong Rec S 19280 (Dec 22, 1995) (statement of Sen Feinstein).

48 Victim Restitution Act of 1995, S Rep No 104-179, 104th Cong, 1st Sess 13 (1995), reprinted in 1996 USCCAN 925.

4918 USC $\$ 3663(\mathrm{a})(1)(\mathrm{A})$.

5018 USC $\$ 3663$ (1988).

51 "The court, when sentencing a defendant convicted of an offense under this title or under subsection (h), (i), (j), or (n) of section 902 of the Federal Aviation Act of 1958 (49 U.S.C. 1472), may order ...." 18 USC $\$ 3663$ (a) (1988).

5218 USC $\$ 3663(a)(1)(B)(i)(I I)$.

5318 USC \& $3663 \mathrm{~A}(\mathrm{c})(1)$.

54 " $[\mathrm{T}]$ he court shall order ... that the defendane make restitution to the victim." 18 USC \$ 3663A(a)(1) (emphasis added). 


\section{B. Circuit Court Cases Dealing with the MVRA}

1. The majority view.

The majority of circuit courts encountering the issue of retroactive application of the MVRA have held that such application would violate the Ex Post Facto Clause. Although some of the circuit courts did not provide any reasons for such a holding, ${ }^{56}$ most of the courts have reasoned both that restitution is a criminal penalty to which the Ex Post Facto Clause applies, and that the MVRA constitutes a substantive change, as required by the Supreme Court test in Weaver. The disagreement dividing the majority and minority views focuses on whether restitution under the MVRA is a civil or criminal penalty; all courts agree that the MVRA constitutes a substantive change."

In United States $v$ Williams, ${ }^{59}$ the Eighth Circuit held that "an order of restitution under the MVRA is punishment for Ex Post Facto Clause purposes." In doing so, the court was forced to distinguish a previous decision involving a different statute, in which the court had held that restitution was not a criminal penalty for purposes of Ex Post Facto Clause analysis. ${ }^{61}$ The court distinguished the previous deci-

55 See United States $v$ Richards, 204 F3d 177, 213 (5th Cir 2000) (accepting the majority view of restitution as a criminal penalty and thus holding that "[r]etroactive application of the MVRA ... would violate the Ex Post Facto Clause"); United States v Edwards, 162 F3d 87, 92 (3d Cir 1998) (finding "that under the MVRA, restitution is punishment, and that retrospective application of that punishment ... is a violation of the Ex Post Facto Clause); United States $v$ Siegel, 153 F3d 1256, 1260 (11th Cir 1998) (stating it was "persuaded by the analysis adopted in the majority of the circuits on this issue" and thus holding "that the MVRA cannot be applied to a person whose criminal conduct occurred prior to April 24, 1996"); United States v Bapack, 129 F3d $1320,1327 \mathrm{n} 13$ (DC Cir 1997) (concluding in a footnote that retroactive application of the MVRA to the defendant would violate the Ex Post Facto Clause); United States $v$ Williams, 128 F3d 1239, 1241 (8th Cir 1997) (concluding that "an order of restitution under the MVRA is punishment for Ex Post Facto Clause purposes"); United States v Baggett, 125 F3d 1319, 1322 (9th Cir 1997) (holding that the court must use the old VWPA "to avoid running afoul of the Ex Post Facto Clause"); United States $v$ Thompson, 113 F3d 13, 15 n 1 (2d Cir 1997) (noting simply that "application of the [MVRA] to this case would be barred by the ex post facto clause").

56 See Bapack, $129 \mathrm{~F} 3 \mathrm{~d}$ at $1327 \mathrm{n} 13$ (making the statement in a footnote without any analysis); Thompson, $113 \mathrm{~F} 3 \mathrm{~d}$ at $15 \mathrm{n} 1$ (same).

57 See Weaver, 450 US 24 . See also text accompanying notes 25-27.

58 See note 11.

59128 F3d 1239 (8th Cir 1997).

60 Id at 1241. Although the court determined that retroactive application of the MVRA would violate the Ex Post Facto Clause, the court held that in this case the restitution order was permissible because the order was based on an offense that occurred on May 30,1996, a month after the MVRA was enacted. Id.

61 See United States v Crawford, 115 F3d 1397, 1403 (8th Cir 1997) (holding that restitution is not punishment within the meaning of the Ex Post Facto Clause). The statute at issue in Crawford is the Child Support Recovery Act of 1992 ("CSRA"), 18 USC $\S 228$ (1994). This Act was also the subject of a number of ex post facto challenges. The CSRA punishes a person who "willfully fails to pay a past due support obligation with respect to a child who resides in another State." Id $\S 228(a)$. The Act contains two separate sections, one entitled "Punishment" and the other entitled "Restitution." Id $\S 228$ (b), (c). The Restitution section directs a court to "order res- 
sion on the ground that the plain wording of the MVRA compelled a different result. ${ }^{62}$ In making this determination, the court looked to a phrase contained in the MVRA stating that the court may order restitution "in addition to ... any other penalty authorized by law." The use of the word "penalty" was considered to be dispositive evidence that restitution under the MVRA was "punishment for Ex Post Facto Clause purposes.",64

In United States $v$ Siegel, ${ }^{65}$ the Eleventh Circuit began its examination of whether retroactive application of the MVRA was impermissible by considering the statutory language of the Act. ${ }^{66}$ Much like the Eighth Circuit in Williams, ${ }^{67}$ the Eleventh Circuit emphasized the word "penalty" and held that the plain meaning of the statute required characterizing restitution as a criminal penalty. ${ }^{68}$ The court bolstered its conclusion by citing its own and other circuit courts' precedent, outside the context of the Ex Post Facto Clause, that characterized restitution as a criminal penalty. ${ }^{69}$ Based on these precedents, the

titution ... in an amount equal to the past due support obligation as it exists at the time of sentencing." Id \& 228(c). Unlike the MVRA, the CSRA has uniformly withstood ex post facto challenges. One key difference between the CSRA and the MVRA is that failure to pay child support can be viewed as a new offense. In other words, although a parent may be guilty of not paying child support before the CSRA was enacted, if the parent has still not paid it at some point after the enactment, the offense is a new willful failure to pay a past due child support obligation. The Eighth Circuit held that the CSRA did not violate the Ex Post Facto Clause on two grounds. One was that restitution was not "punishment" as discussed in the text. However, the alternative holding was that there was no retroactive application because the defendant committed the crime after the enactment date by still refusing to pay. This type of reasoning was also employed by the Fifth Circuit in United States $v$ Rose, 153 F3d 208 (5th Cir 1998). The court noted that the CSRA did not apply retrospectively because there is no change in legal obligations. Id at 209-10. The Fifth Circuit explicitly noted that it refused to base its holding even in part on the notion that "restitution does not constitute punishment within the meaning of the Ex Post Facto Clause." Id at $211 \mathrm{n} 1$. This was based on its prior precedent characterizing restitution as a criminal penalty. Id. The other courts that have held the CSRA does not violate the Ex Post Facto Clause are the Seventh and Tenth Circuits in United States v Black, 125 F3d 454 (7th Cir 1997), and United States v Hampshire, 95 F3d 999 (10th Cir 1996), respectively. Both of these courts have based their holdings on the view of restitution under the CSRA as a civil remedy, which is consistent with their view of restitution under the MVRA.

62 Williams, 128 F3d at 1241.

63 Id, quoting 18 USC $\$ 3663 \mathrm{~A}(\mathrm{a})(1)$.

64 Williams, $128 \mathrm{~F} 3 \mathrm{~d}$ at 1241 . The court did not address the fact that a penalty can also be civil, an issue that the Seventh Circuit later raised. See text accompanying notes 92-93.

65153 F3d 1256 (11th Cir 1998).

66 Id at 1259.

67 See notes 59-64 and accompanying text.

68 Siegel, $153 \mathrm{~F} 3 \mathrm{~d}$ at 1259.

69 See United States $v$ Twitty, 107 F3d 1482, 1493 n 12 (11th Cir 1997) (asserting restitution is "a criminal penalty meant to have strong deterrent and rehabilitative effect"), quoting United States $v$ Hairston, 888 F2d 1349, 1355 (11th Cir 1989). For a case outside the Eleventh Circuit, see United States v Dubose, 146 F3d 1141, 1144 (9th Cir 1998) (contending that restitution under the MVRA is punishment because it has "deterrent, rehabilitative, and retributive purposes" in the context of an Eighth Amendment challenge). 
court concluded that "restitution under the MVRA is a [criminal] penalty." Accordingly, it held that retroactive application of the MVRA was impermissible.

In United States $v$ Edwards, the Third Circuit also espoused the majority view. ${ }^{72}$ The Third Circuit discussed United States $v$ Newman, ${ }^{73}$ but stated that it believed "the majority view [to be] the better view." The court based its interpretation on the "statutory scheme and the legislative history of the MVRA.," The court believed that the inclusion of restitution as "an integral and necessary part of sentencing, supervised release, and probation for the crimes it implicates" in the statutory scheme demonstrated that Congress viewed restitution as a criminal penalty. ${ }^{76}$ Additionally, the Third Circuit referenced the MVRA's legislative history to support its view. ${ }^{7}$ In particular, it indicated that the legislative history demonstrated that Congress believed "mandatory restitution forces an individual defendant to address the harm his crime has caused to the individual victims of his crime and to society." legislative history convinced the court that restitution was a criminal penalty under the statute, and that retroactive application of the MVRA violated the Ex Post Facto Clause.

Recently, the Fifth Circuit has joined the majority by holding that restitution is a criminal penalty and therefore retroactive application of the MVRA would violate the Ex Post Facto Clause. Currently, only the First, Fourth, and Sixth Circuits have not expressed an opinion about the permissibility of the retroactive application of the MVRA.

$70 \quad$ Siegel, 153 F3d at 1259.

71 Id at 1260.

72162 F3d 87, 91 (3d Cir 1998).

73144 F3d 531 (7th Cir 1998).

74. Edwards, 162 F3d at 91.

75 Id.

76 Id.

77 Id.

78 Id. Although the court did not quote the particular statements to which it was referring, it did cite to particular congressional reports. The legislative history of the statute will be examined in further detail in Part III.A.2.

79 See United States v Sleight, 808 F2d 1012, 1020 (3d Cir 1987) (despite compensatory aspects, restitution remains "inherently a criminal penalty"); United States $v$ Palma, 760 F2d 475, 479-80 (3d Cir 1985) (holding that restitution under the VWPA is a criminal penalty).

80 Edwards, 162 F3d at 91-92.

81 United States $v$ Richards, 204 F3d 177, 213 (5th Cir 2000) (holding its own precedent regarding restitution prevented it from accepting the minority view). See, for example, Rose, 153 F3d at 211 n 1 (stating that the court's prior holdings that restitution is "at least in part, penal" prevent the court from adopting the reasoning that restitution under the CSRA is not punishment); United States $v$ Corn, 836 F2d 889, 895-96 (5th Cir 1988) (holding that retroactive application of the VWPA violates the Ex Post Facto Clause).

82 However, these courts' precedents indicate they would probably join the majority view. 
2. The minority view.

The Seventh Circuit created a circuit split in 1998, with its ruling in Newman. In Newman, the court held retroactive application of the MVRA did not violate the Ex Post Facto Clause because restitution was a civil, not a criminal, penalty. ${ }^{84}$ The court based this conclusion on a number of factors. First, it noted the traditional view of restitution as an "equitable device for restoring victims to the position they had occupied prior to a wrongdoer's actions." ${ }^{, 85}$ The court then cited cases holding that restitution was mainly a compensatory device, and not punitive. ${ }^{86}$ The Seventh Circuit highlighted one of its own cases, in which it had held under a different statute that "[r]estitution is not 'punishment' within the meaning of the Ex Post Facto Clause.," The court drew further support for its conclusion that restitution is not a criminal penalty from the Supreme Court's guidelines regarding the civil/criminal distinction. ${ }^{88}$

The Seventh Circuit first examined the statute, pursuant to the Supreme Court guidelines, ${ }^{89}$ to determine if Congress had expressed a clear intent to designate restitution as civil or criminal. ${ }^{90}$ Unlike the Eighth Circuit," the Seventh Circuit hesitated to give too much weight

The First Circuit held in United States v Gilberg that retroactive application of the 1990 amended VWPA would violate the Ex Post Facto Clause because restitution was part of the criminal sentence. 75 F3d 15, 22 (1st Cir 1996). And both the Fourth and Sixth Circuits issued recent opinions stating restitution under the VWPA and MVRA was a criminal penalty, although these cases did not arise explicitly within the context of the Ex Post Facto Clause. See United States $v$ Karam, 201 F3d 320, 328 (4th Cir 2000) (asserting "restitution under the VWPA is primarily penal in nature"); United States $v$ Vandeberg, 201 F3d 805, 814 (6th Cir 2000) (declaring "[r]estitution is a part of one's sentence under the statutory scheme" of the MVRA and thus a defendant must have the criminal protection of having an "opportunity to be heard").

83144 F3d 531.

84 Id at 542. Although the Seventh Circuit reached a different conclusion than the other courts, it did note its agreement regarding the "substantive change" created by the MVRA. Id at $537 \mathrm{n} 5$. A substantive change is required by the Supreme Court in Weaver. See text accompanying notes 25-27. The court stated that removing the discretionary power of the judge to award restitution as well as making the defendant's financial status irrelevant did signify an "increase" in punishment. Newman, $144 \mathrm{~F} 3 \mathrm{~d}$ at $537 \mathrm{n} 5$. Thus, the only element saving retroactive application of the MVRA from violating the Ex Post Facto Clause is the fact that it is a civil penaity.

85 Id at 538.

86 Id at 538-39. See, for example, United States v Gifford, 90 F3d 160, 163 (6th Cir 1996) (stating "a primary purpose of restitution is to compensate the innocent victim of a crime"); United States v Rochester, 898 F2d 971, 983 (5th Cir 1990) (stating "the purpose of the VWPA is 'to ensure that wrongdoers, to the degree possible, make their victims whole"') (citation omitted).

87 Newman, 144 F3d at 538-39, quoting United States v Black, 125 F3d 454, 467 (7th Cir 1997) (involving the CSRA). Unlike the Eighth Circuit, the Seventh Circuit did not draw a distinction between the two acts. See note 61 and accompanying text.

88 See Newman, 144 F3d at 540. See also Part I.

89 See notes 31-34 and accompanying text.

90 Newman, 144 F3d at $540-41$.

91 See Williams, 128 F3d at 1241. 
to the word "penalty" in the statute..$^{92}$ It noted that the word "penalty" could refer to either a civil or criminal penalty and that even the Supreme Court has used the word penalty to describe a "civil penalty." Finding no conclusive evidence in the express language of the statute, the court proceeded to examine the seven factors set forth by the Supreme Court in Mendoza-Martinez."

Upon applying the factors, the court determined that restitution was "not 'so punitive either in purpose or effect' as to acquire a criminal character." As for the first factor, the court stated that restitution was not an affirmative disability or restraint because it was not analogous to imprisonment. ${ }^{96}$ The second factor examines the historical view of the sanction, and the court declared that "historically, restitution has been considered an equitable, remedial measure." The third factor, regarding scienter, also supported the non-punitive nature of restitution because the MVRA did not have an independent requirement of scienter for restitution to be applicable. The court combined the fourth, sixth, and seventh factors regarding the purposes of the sanction to note that the primary purpose of restitution was not retribution and deterrence, but compensation for the victims. ${ }^{99}$ Although the fifth factor (whether the behavior to which the sanction applies is already a crime) weighed toward the criminal side, the court believed that, on balance, the factors leaned overwhelmingly toward a civil characterization. ${ }^{100}$ The Seventh Circuit thereby concluded that restitution under the MVRA was "not a criminal punishment for purposes of the Ex Post Facto Clause."

The Seventh Circuit has gained one supporter, the Tenth Circuit. The Tenth Circuit confronted the ex post facto issue in an emotionally charged case involving Terry Lynn Nichols, a coconspirator in the

92 Newman, 144 F3d at 540 n 9.

93 Id. See Hudson v United States, 522 US 93, 99 (1997) ("Even in those cases where the legislature 'has indicated an intention to establish a civil penalty, we have inquired further whether the statutory scheme was so punitive either in purpose or effect,' as to 'transfor[m] what was clearly intended as a civil remedy into a criminal penalty.") (citations omitted).

94 See text accompanying notes $35-41$.

95 Newman, 144 F3d at 540 (citations omitted).

96 Id at $540-41$.

97 Id.

98 Id.

99 Id at 541-42.

100 Id at $541 \mathrm{n} 10$.

101 Id at 542. Although in the minority, the Seventh Circuit has continually rejected opportunities to overrule itself. See United States v Lopez, 222 F3d 428, 440 (7th Cir 2000) ("declin[ing] to reconsider the holding in Newman"); United States v Bach, 172 F3d 520, 522-23 (7th Cir 1999) (declining the defendant's invitation to overrule Newman, stating "[o]urs is a minority view, but we think it is correct") (citations omitted); United States $v$ Szarwark, 168 F3d 993, 998 (7th Cir 1999) (reversing the district court opinion that retroactive application of the MVRA violated the Ex Post Facto Clause). 
Oklahoma City bombing. ${ }^{102}$ In United States $v$ Nichols,${ }^{103}$ the court relied mainly on its own precedent to determine whether restitution under the MVRA was a civil or criminal penalty. ${ }^{104}$ The court examined previous cases holding restitution was not punitive in nature. ${ }^{105}$ Based on these cases, the Tenth Circuit concluded that "the law in this circuit has been established ... and we are obliged to follow it." In holding that restitution was not punishment under the Ex Post Facto Clause and that retroactive application of the MVRA was thereby permissible, the court noted that it "accept[ed] the view of the Seventh Circuit ... and reject[ed] the views of the Second, Third, Eighth, Ninth, Eleventh and D.C. Circuits to the contrary."107

\section{Classifying RESTITUTION UNDER THE MVRA}

This Comment offers a solution to the debate among the circuit courts regarding the retroactive application of the MVRA. The methods used by the various circuit courts permit characterizing restitution under the MVRA as either a civil or criminal penalty. However, since labeling restitution under the MVRA as a civil penalty would trigger Seventh Amendment concerns, possibly invalidating the statute, courts should classify restitution under the MVRA as a criminal penalty. In light of this determination, retroactive application of the MVRA would violate the Ex Post Facto Clause.

\section{A. Reasoning by the Circuit Courts}

The Seventh Circuit, which expounds the minority position, has provided the most comprehensive evaluation of the issue. This Comment attempts to engage in a thorough analysis to support the majority view, which has heretofore been underdeveloped. Some of the circuit courts on the majority side have given no reasons at all for their

102 See, for example, Lisa Anderson, Now Fear Grips Even Small Towns, Chi Trib N16 (Apr 20,1995) (detailing the aftermath of the Oklahoma City bombing); James C. McKinley, Jr., Terror in Oklahoma City: Around the Nation Aftershocks of Terror Spread Out Quickly after the Explosion in Oklahoma City, NY Times B10 (Apr 20, 1995) (describing the fear people felt after the bombing); Sue Anne Pressley, Bomb Kills Dozens in Oklahoma Federal Building, Wash Post A1 (Apr 20,1995) (describing the scene of the bombing).

103169 F3d 1255 (10th Cir 1999).

104 Id at 1279-80.

105 See United States v Hampshire, 95 F3d 999, 1006 (10th Cir 1996) (holding restitution under the CSRA was not criminal punishment); United States $v$ Arutunoff, 1 F3d 1112, 1121 (10th Cir 1993) ("The VWPA's purpose is not to punish defendants or to provide a windfall for crime victims but rather to ensure that victims, to the greatest extent possible, are made whole for their losses."). 1121.

106 Nichols, 169 F3d at 1279-80, citing Hampshire, 95 F3d at 1006, and Arutunoff, 1 F3d at

107 Nichols, 169 F3d at 1280 n 9. 
holdings. ${ }^{108}$ Others have not clearly refuted the Seventh Circuit's reasons. ${ }^{109}$ Circuit courts on both sides (such as the Fifth and Tenth Circuits) rely heavily on their own precedent, although their opposing views demonstrate that the case law regarding the nature of restitution is mixed. ${ }^{110}$ Those courts that have addressed the issue in detail have relied on the express statutory language, legislative history, and, in the Seventh Circuit's case, factors mandated by the Supreme Court. However, as will be demonstrated, these approaches do not lead to a clear solution and instead only prove that either interpretation of restitution under the MVRA is plausible. This Comment aims to provide a lucid and doctrinally sound justification for the majority's conclusion.

\section{Text of the MVRA.}

The Eighth and Eleventh Circuits relied on the express language of the statute to determine whether it was criminal or civil."1 In particular, both courts focused on the statutory term "penalty." However, these courts did not explain why the word penalty, without a qualifier, definitively means a "criminal penalty." As the Seventh Circuit pointed out, the Supreme Court has used the word "penalty" in conjunction with the word "civil" to mean a civil remedy. ${ }^{12}$ Congress also recognizes both civil and criminal penalties. It has enacted a number of statutes in which it uses the term "civil penalty" to designate a remedy that is available in a civil suit. ${ }^{113}$ In addition, in statutes that make no reference to a "civil penalty," Congress has still used the term "criminal penalty." Congress may have feared that the word "penalty," without a qualifier, would be ambiguous. Since Congress recognizes both civil and criminal penalties and has labeled them as such in

108 See note 56.

109 See, for example, Siegel, 153 F3d at 1259 (not explaining why "penalty" necessarily means a criminal penalty as opposed to a civil penalty).

110 See notes 81 and 105.

111 See Williams, 128 F3d at 1241; Siegel, 153 F3d at 1259.

112 Newman, 144 F3d at $540 \mathrm{n} 9$. See also note 93 and accompanying text.

113 See 15 USC \& 80b-9(e)(1) (1994) (noting that the Securities and Exchange Commission could "bring an action in a United States district court to seek ... a civil penalty"); 15 USC $\$ 687 \mathrm{~g}(\mathrm{a})$ (1994) ("The civil penalties provided for in this section ... may be recovered in a civil action."); 33 USC $\S 944(\mathrm{~h})$ (1994) ("All civil penalties ... shall be collected by civil suit."). See also 18 USC $\$ \S 2248,2259,2264,2327$ (1994 \& Supp 1998) (all containing the phrase "any other civil or criminal penalty") (emphasis added).

114 See, for example, 18 USC $\S 2332$ (1994) (entitled “Criminal penalties"); 20 USC $\$ 1097$ (1994) (same); 10 USC $\$ 2408$ (1994) (entitled "Prohibition on persons convicted of defense contract related felonies and related criminal penalties on defense contractors"); 10 USC $\$ 2538(\mathrm{f})$ (1994) (listing the "criminal penalty" for a violation). 
various statutes, the word "penalty" without a qualifier does not signal necessarily that Congress intended for restitution to be criminal."

\section{Legislative history.}

The Third Circuit also relied on legislative history to support its conclusion. Although legislative history is regularly used by courts in statutory interpretation, in recent years the Supreme Court has expressed some skepticism about its usefulness. ${ }^{116}$ In Carter $v$ United States, ${ }^{117}$ the Court asserted that its approach to statutory interpretation "begin[s] by examining the text, not by 'psychoanalyzing those who enacted it." not enacted as law, legislative history is also often ambiguous or contradictory. ${ }^{119}$ Despite the weaknesses of legislative history, the Supreme Court continues to consider it in some cases ${ }^{120}$ and the Third Circuit used it to interpret the MVRA.

115 The statutory language of Section 3664 , which is the procedural mechanism for both the MVRA and the VWPA, also demonstrates that both views of restitution are equally supported. Section 3664 provides that "an order of restitution may be enforced by the United States." 18 USC $\S 3664(m)(1)(A)(i)$ (1994 \& Supp 1998). One of the main features distinguishing the criminal system from the civil system is that the United States is a party to the case instead of the victim. See Stephen Schafer, Restitution to Victims of Crime 8 (Stevens \& Sons 1960) (noting "the conventional view is that crime is an offense against the state, while a tort is an offense against individual rights only"). Allowing the United States to enforce the restitution order reinforces the view that restitution is a criminal penalty. However, this is not the only means of enforcement. Section 3664 also states, "At the request of a victim named in a restitution order, the clerk of the court shall issue an abstract of judgment certifying that judgment has been entered in favor of such victim in the amount specified in the restitution order." 18 USC $\S 3664(\mathrm{~m})(1)(B)$ (Supp 1998). This judgment serves as "a lien on the property of the defendant" in the same manner "as a judgment of a court of general jurisdiction." Id. This method of enforcement supports a civil view of restitution, because the victim is allowed to enforce the order like a civil judgment. Thus, the enforcement provision does not resolve the issue.

116 See Thomas Merrill, Textualism and the Future of the Chevron Doctrine, 72 Wash U L Q 351,355 (1994) (revealing statistics that demonstrate that the Court used legislative history less in 1992 than in 1981). Merrill attributed this trend to Justice Scalia and Justice Thomas, both of whom refuse to join a majority opinion that relies on legislative history. Id at 365 .

117530 US 255 (2000).

118 Id at 2170, quoting Bank One Chicago, NA v Midwest Bank \& Trust Co, 516 US 264, 279 (1996) (Scalia concurring in part and concurring in judgment).

119 See Wisconsin Public Intervenor v Mortier, 501 US 597, 622-23 (1991) (Scalia concurring) (criticizing the majority's use of legislative history); Abourezk v Reagan, 785 F2d 1043, 1054 n 11 (DC Cir 1986) ("Committee reports, we remind, do not embody the law."). See also Patricia Wald, Some Observations on the Use of Legislative History in the 1981 Supreme Court Term, 68 Iowa L Rev 195, 214 (1983) ("It sometimes seems that citing legislative history is still, as my late colleague Harold Leventhal once observed, akin to 'looking over a crowd and picking out your friends."”).

120 The majority of the Court still considers clear legislative history a valuable aid for interpreting ambiguous text. Wisconsin Public Intervenor, 501 US at $610 \mathrm{n} 10$. Even Justice Scalia will use legislative history to disconfirm an absurd result. Green v Bock Laundry Machine Co, 490 US 504, 527 (1989) (Scalia concurring). 
The Third Circuit's remarks regarding legislative history were conclusory at best, and did not cite the express language that supported its characterization of restitution as a criminal penalty. ${ }^{121} \mathrm{~A}$ brief perusal of those legislative reports that the Third Circuit identified reveals that, contrary to the Third Circuit's assertions, the legislative history of the MVRA is ambiguous.

On the one hand, the purpose of the MVRA as stated in the committee report is "to ensure that the loss to crime victims is recognized, and that they receive the restitution that they are due." ${ }^{122}$ This statement supports the compensatory view of restitution, which leads to a civil label. ${ }^{123}$ But, in the discussion that follows, the report also notes that "this position underestimates ... the potential penalogical benefits of requiring the offender to be accountable for the harm caused to the victim." ${ }^{124}$ The idea of penological benefit supports the retributive purpose of restitution, which leads to a criminal characterization.

Statements by various members of Congress also support both notions of restitution. In fact, some members even referred to the MVRA as serving two purposes simultaneously, one compensatory and one retributive. Senator Hatch, a cosponsor of the Bill, stated that mandatory restitution can "provide important closure to victims of crime." ${ }^{\text {"26 }}$ But he also declared, "[r]estitution has an important penological function as well.... it forces the criminal to contemplate his criminal act and truly pay for the crime." ${ }^{127}$ Senator Biden, the other cosponsor, emphasized as problematic that "the victim's lossesemotional, physical, and financial losses - often go completely uncompensated." are not alone. We will demand accountability from your wrongdoers, and we understand that criminals owe a debt not only to society but to

121 Edwards, 162 F3d at 91.

122 S Rep No 104-179 at 12 (cited in note 48).

123 See Note, Victim Restitution in the Criminal Process: A Procedural Analysis, 97 Harv L Rev 931,934-35 (1984) (noting "the traditional model of the legal system," in which "the goal of civil law is to compensate private wrongs, whereas the aims of the criminal law are to redress public wrongs and to protect society by punishing those whose behavior is morally culpable").

124 S Rep No 104-179 at 18 (cited in note 48).

125 See Kelly $v$ Robinson, 479 US 36, 53 (1986) (stating that "criminal proceedings focus on the State's interests in rehabilitation and punishment, rather than the victim's desire for compensation").

126141 Cong Rec at S 19278 (cited in note 45) (statement of Sen Hatch). Senator Hatch further states, "Far too often our criminal justice system appears to ignore the victims of crime. It frequently seems that only criminals have rights in the system.... The order of restitution represents the justice system's recognition that a real person, not only society, has suffered a wrong." Id at S 19277-78.

127 Id at S 19278.

128 Id (statement of Sen Biden). 
you." ${ }^{129}$ Senator Feinstein stated, "Victim restitution is a matter of simple justice. If somebody has been hurt by a criminal, they should be made whole." ${ }^{130}$ Senator Leahy noted, "We can do more to see that victims of crime ... are treated with dignity and assisted and compensated with Government help." ${ }^{131}$ The legislative history includes remarks on both the compensatory and punitive goals of restitution, supporting both the civil and criminal nature of restitution. ${ }^{132}$ This result is unsurprising - the two purposes are not mutually exclusive. ${ }^{1.3}$

\section{The Kennedy $v$ Mendoza-Martinez factors.}

Despite holding the minority viewpoint, the Seventh Circuit was the only circuit court to rely on the seven Supreme Court civil/criminal factors in evaluating the issue. ${ }^{134}$ The Seventh Circuit believed that these factors weighed in favor of viewing restitution as a civil penalty. However, an examination of these factors demonstrates that such a result is not clear. Some of the factors do support the Seventh Circuit's view of the civil nature of restitution. For example, the first factor is " $[w]$ hether the sanction involves an affirmative disability or restraint." ${ }^{135}$ As the Supreme Court has noted, "[monetary] sanctions [ ] do not involve an 'affirmative disability or restraint,' as that term is normally understood." ${ }^{, 136}$ Also in favor of the civil view is the third factor, "whether [the sanction] comes into play only on a finding of scienter." ${ }^{, 137}$ Since restitution is mandatory, it is ordered without regard to the defendant's state of mind. Although the underlying criminal statute probably would include a scienter requirement, there is no independent scienter requirement for restitution itself, as noted by the Seventh Circuit. ${ }^{138}$ Finally the last two factors also support the civil nature of restitution. These are "whether an alternative purpose to which

129 Id. Sen Biden further stated, "[t]his bill also sends an important message to criminals you must take responsibility for [y]our actions, and you will pay for the pain you have caused." Id at $S$ 19278-79.

130 Id at S 19280 (statement of Sen Feinstein).

131 Id at S 19279 (statement of Sen Leahy).

132142 Cong Rec H 3606 (April 18, 1996) (statement of Rep Hyde) ("Think of victims and think of victims first."). Congressman Buyer remarked, "Not only will the criminal have to pay a debt to society, the criminal will also have to make amends to the victim." Id at H 3609 (statement of Rep Buyer).

133 See Hudson v United States, 522 US 93, 105 (1997) (noting that a sanction may both deter and serve civil purposes at the same time).

134 See text accompanying note 36 .

135 Mendoza-Martinez, 372 US at 168.

136 Hudson v United States, 522 US 93, 104 (1997). See also Flemming v Nestor, 363 US 603, 617 (1960) (noting that a mere denial of a benefit is not an affirmative disability or restraint and is "certainly nothing approaching the 'infamous punishment' of imprisonment").

137 Mendoza-Martinez, 372 US at 168.

138 See Newman, 144 F3d at 541. 
[the sanction] may rationally be connected is assignable for it, and whether it appears excessive in relation to this alternative purpose assigned." ${ }^{139}$ The alternative purpose for restitution besides deterrence and retribution is compensation. As a compensatory device, restitution does not seem excessive for its purpose; it merely seeks to make the victim of a crime whole. Thus, these factors, as declared by the Seventh Circuit, can be read to support a civil view of restitution.

However, some of the factors on which the Seventh Circuit relied do not easily support viewing restitution as a civil penalty. The second factor is "whether [the sanction] has historically been regarded as a punishment." ${ }^{\prime 40}$ The Seventh Circuit claimed that, historically, restitution has been viewed as an equitable measure. ${ }^{141}$ In general, Supreme Court precedent regarding monetary penalties supports this view. The Supreme Court has stated that "neither money penalties nor debarment has historically been viewed as punishment." ${ }^{142}$ And it has also asserted that "[i]n spite of [monetary penalties'] comparative severity, such sanctions have been upheld against the contention that they are essentially criminal." ${ }^{143}$

The Ninth Circuit disputed the Seventh Circuit's historical view of restitution in United States $v$ Dubose, ${ }^{144}$ stating that "restitution has historically been understood as punishment." Many commentators share this view. One contends that "restitution has been employed as a punitive sanction throughout history." that "[w]hile the use of restitution as a criminal sanction began in the Germanic areas of Europe during the Middle Ages, American legal scholars have traced the modern imposition of judicial restitution orders to some of the earliest penal codes of the United States." ${ }^{\text {,177 }}$ Yet another commentator states that the "view [of] restitution as only a civil remedy and not [] an appropriate criminal sanction. . . . is con-

139 Mendoza-Martinez, 372 US at $168-69$.

140 Id at 168.

141 Newman, 144 F3d at 538.

142 Hudson, 522 US at 104.

143 Helvering v Mitchell, 303 US 391, 400 (1938).

144146 F3d 1141 (9th Cir 1998).

145 Id at 1145.

146 Note, 97 Harv L Rev at 933 (cited in note 123). See also United States v Carrara, 49 F3d 105, 108 (3d Cir 1995) ("Historically, restitution has occupied a prominent penological position.").

147 Lionel M. Lavenue, The Corporation as a Criminal Defendant and Restitution as a Criminal Remedy: Application of the Victim and Witness Protection Act by the Federal Sentencing Guidelines for Organizations, $18 \mathrm{~J}$ Corp L 441, 454 (1993) (discussing the history of restitution as a criminal penalty); Catherine M. Goodwin, The Imposition of Restitution in Federal Criminal Cases, 62 Fed Prob 95, 95 (1998) ("The principle of restitution is an integral part of virtually every formal system of criminal justice, of every culture and every time."), quoting United States $v$ Webb, 30 F3d 687, 689 (6th Cir 1994). 
trary to historical precedent."148 Indeed, although the Supreme Court has not commented on the historical view of restitution, it allowed restitution to be a condition for a pardon in 1913 in Bradford $v$ United States. ${ }^{149}$

The Seventh Circuit also believed that the fourth factor, "whether [the sanction's] operation will promote the traditional aims of punishment - retribution and deterrence,"150 supported its view. The Seventh Circuit asserted that although these purposes may be promoted by restitution, its primary purpose is compensatory. ${ }^{151}$ However, precedent is more mixed on this topic. ${ }^{152}$ In Kelly $v$ Robinson, ${ }^{153}$ the Supreme Court stated that restitution furthered rehabilitative and deterrent goals of the criminal system. ${ }^{154}$ It noted that restitution was "an effective rehabilitative penalty because it forces the defendant to confront, in concrete terms, the harm his actions have caused." sized the deterrent effect of restitution, stating the "direct relation between the harm and the punishment gives restitution a more precise deterrent effect than a traditional fine." ${ }^{156}$ Since restitution seems to serve both compensatory and punitive purposes, it is difficult to say with certainty which is the primary purpose.

Finally, one factor weighs clearly against restitution as a civil penalty, a factor that the Seventh Circuit relegated to a footnote in $\mathrm{New}$ man. ${ }^{158}$ This factor is "whether the behavior to which [the penalty] applies is already a crime." ${ }^{159}$ As the Seventh Circuit admitted, since the

148 David A. Starkweather, Note, The Retributive Theory of "Just Deserts" and Victim Participation in Plea Bargaining, 67 Ind L J 853, 859 (1992) (analyzing victims' rights of participation in the criminal process under a just deserts theory of retribution). See also Schafer, Restitution to Victims of Crime at 3-7 (cited in note 115) (describing the historical origin of restitution as punishment).

149228 US 446 (1913). Thus, whether restitution has historically been viewed as a criminal sanction or civil remedy is unclear.

150 Mendoza-Martinez, 372 US at 168.

151 See Newman, 144 F3d at 542.

152 See Dubose, 146 F3d at 1144 (holding "restitution under the MVRA is punishment because the MVRA has not only remedial, but also deterrent, rehabilitative, and retributive purposes"); United States v Hairston, 888 F2d 1349, 1355 (11th Cir 1989) (stating "[r]estitution is not a civil matter; it is a criminal penalty meant to have strong deterrent and rehabilitative effect"); United States v Brown, 744 F2d 905, 909 (2d Cir 1984) (remarking "[r]estitution undoubtedly serves traditional purposes of punishment" and discussing its deterrent effect).

153479 US 36 (1986) (holding that restitution obligation§ are not dischargeable in a bankruptcy proceeding).

154 Id at $49 \mathrm{n} 10$.

155 Id.

156 Id.

157 The Supreme Court has recognized that "all civil penalties have some deterrent effect." Hudson, 522 US at 102. Thus the "mere presence of a deterrent purpose" does not render a sanction criminal. Id at 105.

158 See 144 F3d at 541 n 10.

159 Mendoza-Martinez, 372 US at 168. 
MVRA and VWPA only award restitution for criminal violations, the underlying act will always be a criminal one. ${ }^{160}$

Based on the seven factors enunciated by the Supreme Court, it is evident that restitution has a dual purpose as both a compensatory and punitive device. As one court noted, "Criminal restitution rests with one foot in the world of criminal procedure and sentencing and the other in civil procedure and remedy." ${ }^{161}$ Both interpretations of restitution under the MVRA are plausible. Consequently, one must look beyond the statutory text, legislative history, and the seven $\mathrm{Su}$ preme Court factors in determining whether restitution under the MVRA is civil or criminal.

Although there are two equally plausible interpretations of the MVRA, the consequences of the interpretations are not the same. As will be demonstrated, construing restitution as a civil penalty implicates serious constitutional doubt regarding the MVRA. Applying the canon of constitutional avoidance results in characterizing restitution under the MVRA as a criminal penalty.

\section{B. The Seventh Amendment Conundrum}

1. The canon of constitutional avoidance.

The Supreme Court has stated that to determine "[w]hether a particular punishment is criminal or civil is, at least initially, a matter of statutory construction." ${ }^{162}$ Various methods of statutory construction employed thus far, such as the express language of the statute and the legislative history, have proven ineffective in resolving the debate between the two interpretations of the MVRA. This Comment argues that the well-established doctrine of constitutional avoidance ${ }^{163}$ sheds some light on the otherwise murky statute. The doctrine of constitutional avoidance argues that when there are two interpretations of a statute and one of those is subject to serious constitutional doubt, the court should reject the constitutionally questionable interpretation. Since construing restitution under the MVRA as a civil penalty sub-

160 Newman, 144 F3d at 541 n 10.

161 United States $v$ Bruchey, 810 F2d 456, 461 (4th Cir 1987) (holding that it impermissible to force a defendant to sign a promissory note requiring long term payments in restitution to a victim).

162 Hudson v United States, 522 US 93, 99 (1997).

163 See Edward J. DeBartolo Corp v Florida Gulf Coast Bldg \& Constr Trades Council, 485 US 568, 575 (1988) ("[W]here an otherwise acceptable construction of a statute would raise serious constitutional problems, the Court will construe the statute to avoid such problems unless such construction is plainly contrary to the intent of Congress."). The Court also emphasized that "[t]his cardinal principle ... has for so long been applied by this Court that it is beyond debate." Id. See also Cass R. Sunstein, Interpreting Statutes in the Regulatory State, 103 Harv L Rev 405, 468 (1989) (stating "constitutional norms deserve a prominent place in statutory interpretation"). 
jects the statute to serious constitutional doubt in light of the Seventh Amendment, restitution under the MVRA should be construed as a criminal penalty.

Adrian Vermeule has explained, "Avoidance is perhaps the preeminent canon of federal statutory construction; its pedigree is so venerable that the Supreme Court invoked its reasoning even before Marbury $v$. Madison established the power of substantive judicial review." ${ }^{164}$ Other commentators have traced the general principle of avoidance to Alexander Murray $v$ Charming Betsy, ${ }^{165}$ in which the Court stated, "[A]n act of congress ought never to be construed to violate the law of nations, if any other possible construction remains." However, Justice Brandeis provided the first detailed explanation of the canon in Ashwander $v$ Tennessee Valley Authority. ${ }^{167}$ He reasoned:

When the validity of an act of the Congress is drawn in question, and even if a serious doubt of constitutionality is raised, it is a cardinal principle that this Court will first ascertain whether a construction of the statute is fairly possible by which the constitutional question may be avoided.

In other words, where there are two interpretations and one is subject to serious constitutional doubt, a court should construe the statute to adopt the other, constitutionally sound, interpretation. All that is required is that one interpretation might be unconstitutional. ${ }^{16}$

Applying constitutional avoidance to the issue at hand means that interpreting the MVRA to construe restitution as a civil penalty would implicate Seventh Amendment concerns, thereby triggering serious constitutional questions about the statute's validity. The MVRA does not provide the defendant with a right to a jury trial on the issue of restitution. It is possible that if restitution is construed as a civil penalty, such a right would be required by the Seventh Amendment and thus, the MVRA would be unconstitutional. The Sixth Amend-

164 Adrian Vermeule, Saving Constructions, 85 Georgetown L J 1945, 1948 (1997), citing Marbury v Madison, 5 US (1 Cranch) 137 (1803). See Mossman v Higginson, 4 US (4 Dall) 12, 13 (1800) (construing Section 11 of the Judiciary Act of 1789 "consistent with the constitution").

1656 US (2 Cranch) 64 (1804) (holding that a foreign ship whose owner had given up U.S. citizenship in favor of Danish citizenship was not subject to forfeiture).

166 Id at 118.

167297 US 288, 346-48 (1936) (Brandeis concurring) (describing rules the Court has developed "under which it has avoided passing upon a large part of all the constitutional questions pressed upon it"). See Ernest A. Young, Constitutional Avoidance, Resistance Norms, and the Preservation of Judicial Review, 78 Tex L Rev 1549, 1574 (2000) (stating constitutional avoidance "has important roots in Justice Brandeis's concurrence in Ashwander").

168 Ashwander, 297 US at 348, quoting Crowell $v$ Benson, 285 US 22, 62 (1932).

169 See Vermeule, 85 Georgetown L J at 1949 (cited in note 164) (noting that the modern approach, which has supplanted the classical approach, "requires only a determination that one plausible reading might be unconstitutional") (emphasis added). 
ment does not pose a similar problem if restitution is considered a criminal penalty. Although the Sixth Amendment provides a defendant with a right to a jury trial, ${ }^{170}$ such a right does not extend to the sentencing phase. ${ }^{171}$ Since interpreting the MVRA to construe restitution as a civil penalty would raise serious Seventh Amendment issues, the canon of constitutional avoidance dictates that this interpretation be avoided. Thus, restitution under the MVRA should be construed as a criminal penalty.

\section{Jury trials and restitution.}

The Seventh Amendment provides a right to a jury trial "[i]n Suits at common law." ${ }^{12}$ If restitution is considered a civil penalty under the MVRA, it is possible that the Seventh Amendment would require that the defendant have a right to a jury trial. Currently the MVRA does not provide such a right. Thus far, the courts have ignored the interaction between the ex post facto issue and the Seventh Amendment issue under the MVRA and VWPA.

All of the appellate courts that have squarely addressed the Seventh Amendment issue under the MVRA or VWPA have held that restitution is a criminal penalty, so the statutes in question did not violate the Seventh Amendment. In Dubose, the Ninth Circuit, in examining whether the MVRA violated the Eighth Amendment, noted "[t]he sanction at issue must be construed as punishment for the Eighth Amendment to be implicated." ${ }^{173}$ It decided that restitution was punishment because it had "deterrent, rehabilitative, and retributive purposes." ${ }^{, 17}$ The Ninth Circuit also based this conclusion on the legislative history of the statute and the historical view of restitution. ${ }^{175}$ When the court next analyzed the Seventh Amendment claim, it relied on the characterization of restitution as punishment to determine that the Seventh Amendment did not apply.

This result comports with the conclusions of numerous courts that have addressed whether the VWPA violates the Seventh Amendment. ${ }^{17}$ For example, in United States $v$ Palma, ${ }^{178}$ the Third Cir-

170 US Const Amend VI.

171 See Spaziano v Florida, 468 US 447, 462-63 (1984) (holding that a sentence need not be imposed by a jury).

172 US Const Amend VII.

173 Dubose, 146 F3d at 1144.

174 Id.

175 Id at 1144-45.

176 Although the court had determined restitution was punishment, it also examined the more complicated claim that the victim enforcement provision transformed the sentencing proceeding into an action at common law. Id at 1148 . The court held that victim enforcement did not alter the statute's underlying criminal nature. Id.

177 See United States v Keith, 754 F2d 1388, 1392 (9th Cir 1985) (stating “Congress made res- 
cuit stated that "an order of restitution imposed under the VWPA is a criminal, rather than civil, penalty" and therefore did not violate the defendant's Seventh Amendment rights. ${ }^{179}$ The court looked to congressional intent and, based on legislative history, stated that "Congress intended restitution to be an integral part of the sentencing process." ${ }^{180}$ In addition, the Third Circuit believed certain aspects of the statute demonstrated that restitution was not a civil penalty. In particular, "the victim [was] limited to recovering certain specified losses and [was] not made a party to the sentencing proceeding." ${ }^{181}$ In fact, no appellate court has decided otherwise, as recently noted by one court: "All circuits that have decided the [Seventh Amendment] issue have held that restitution under the VWPA is penal and that the Seventh Amendment simply does not apply to a determination of the amount of a restitution order."

Both of the minority circuit courts - the Seventh and the Tenthhave had cases before them involving a Seventh Amendment challenge to the VWPA. In United States $v$ Gomer, ${ }^{183}$ the defendant challenged his restitution sentence in front of the Seventh Circuit. ${ }^{1.4} \mathrm{He}$ claimed the judge had failed to consider the "financial needs" of his dependents as directed by the VWPA. ${ }^{185}$ In addition to this statutory claim, he also argued the VWPA was unconstitutional. ${ }^{186}$ The Seventh Circuit resolved the issue on statutory grounds and thereby avoided the constitutional question. ${ }^{187}$ Interestingly, the dissent argued that the court should reach the merits and claimed that the VWPA did not vio-

titution under the Act a criminal penalty" and thus the defendant "was not entitled to a jury trial on the issue of the amount of restitution liability"); United States $v$ Watchman, 749 F2d 616, 617 - (10th Cir 1984) (declaring "[r]estitution is a permissible penalty imposed on the defendant as part of sentencing" and "does not infringe on Seventh Amendment rights"); United States $v$ Brown, 744 F2d 905, 910 (2d Cir 1984) (holding that the "Seventh Amendment is no barrier to this addition [of restitution] to the arsenal of federal criminal sanctions"); United States $v$ Satterfield, 743 F2d 827, 837 (11th Cir 1984) (declaring "[t]here can be little doubt that Congress intended the restitution penalties of the VWPA to be incorporated into the traditional sentencing structure," thus not triggering the protections of the Seventh Amendment); United States $v$ Florence, 741 F2d 1066, 1068 (8th Cir 1984) (asserting restitution under the VWPA "remains an essentially criminal sanction" thus the "restitution does not violate the seventh amendment").

$178760 \mathrm{~F} 2 \mathrm{~d} 475$ (3d Cir 1985).

179 Id at 479 (indicating that the court agreed with every circuit that had considered the issue).

180 Id.

181 Id.

182 See United States $v$ Rostoff, 164 F3d 63, 71 (1st Cir 1999) (finding that an order of restitution without a jury trial did not violate Seventh Amendment or due process).

183764 F2d 1221 (7th Cir 1985) (holding that it is plain error to fail to consider financial needs of dependents as required by the VWPA).

184 Id at 1222.

185 Id.

186 Id.

187 Id at $1222 \mathrm{n} 1$. See also id at $1225 \mathrm{n} 8$. 
late the Seventh Amendment. ${ }^{188}$ In reaching this conclusion, Judge Coffey noted that Congress intended restitution to be "part of the criminal sentencing procedure and [ ] not ... a civil remedy." ever, this is merely dicta in a dissent of a case decided thirteen years before Newman, and it is not surprising that the court in Newman does not address it. The Tenth Circuit, on the other hand, actually decided a case on the Seventh Amendment issue. ${ }^{100}$ In holding that the VWPA was constitutional, the court stated, "Restitution is a permissible penalty imposed on the defendant as part of sentencing." bly, the Tenth Circuit did not mention this case in Nichols.

\section{Application of the canon of avoidance to the MVRA.}

Construing restitution as a civil penalty implicates a serious constitutional question. A court must decide whether an order of restitution would be a "suit at common law." ${ }^{193}$ The consequences of such a designation are serious because the MVRA does not provide a right to a jury trial for restitution orders. Thus, if a court determined that restitution is a legal remedy, the MVRA would be struck down as unconstitutional (probably along with the VWPA). ${ }^{194}$ It is currently unclear whether restitution would be considered a legal or equitable remedy if it were to be classified as a civil penalty. ${ }^{195}$

In United States $v$ Dudley, ${ }^{196}$ the Fourth Circuit held that restitution did not have a purely punitive character and thus did not abate at the death of the accused like most criminal penalties. ${ }^{197}$ However, the court then was forced to decide whether there was a right to a jury since it had classified restitution as a civil penalty. ${ }^{198}$ The court stated that this depended on whether the restitution under the VWPA could

188 Id at 1226 (Coffey dissenting).

189 Id at 1228-29.

190 Watchman, $749 \mathrm{~F} 2 \mathrm{~d}$ at 617 ("[T]he Act insofar as it provides for restitution, and as it provides for the court to determine the amount (if any), is a constitutional extension of sentencing.").

191 Id.

192169 F3d 1255. See text accompanying notes $103-06$.

193 The Seventh Amendment only requires jury trials for "[s]uits at common law." US Const Amend VII. The Seventh Amendment is not applicable to suits in equity.

194 See note 205. Although all the courts addressing the Seventh Amendment question resolved it by stating that restitution was a criminal sanction, those courts characterizing restitution as civil subject the MVRA to possible constitutional invalidation if restitution were determined also to be legal in nature. Since restitution is the same under both the MVRA and the VWPA, such a classification would also expose the VWPA to constitutional invalidation as well.

195 The two circuits holding that restitution under the MVRA is a civil penalty have not yet addressed whether restitution is legal or equitable for the purposes of the Seventh Amendment.

196739 F2d 175 (4th Cir 1984).

197 Id at 177 (stating that there is a "substantial difference between restitution ... and forfeiture").

198 Id at 178. 
be considered an equitable remedy or a legal one. ${ }^{199}$ The court noted the complexity of this question and finally stated, "[i]n short, the question whether a jury hearing must be allowed to preserve the constitutionality of [the statute] is a tangled one, with no sure outcome short of a Supreme Court decision." decide the issue by stating that since the accuracy of the amount of restitution was not contested, there was no need to address the Seventh Amendment issue.

The Supreme Court has implied that restitution would require a jury trial if it were to be labeled as a civil penalty. The Court mentioned in a footnote in Kelly $v$ Robinson, ${ }^{202}$ that "[s] everal lower courts have addressed the constitutionality of the federal Victim and Witness Protection Act." dants have no right to jury trial as to the amount of restitution, even though the Seventh Amendment would require such a trial if the issue were decided in a civil case., ${ }^{204}$ Although this is merely dicta, it strongly implies that construing restitution as a civil penalty would trigger a right to a jury trial under the Seventh Amendment. Such a civil construction could lead to a finding that the MVRA and VWPA are unconstitutional. With regard to the VWPA, some commentators have made this argument, contending that restitution is a civil, legal remedy and that the statute is thereby unconstitutional because it violates the Seventh Amendment. ${ }^{205}$

Under the canon of constitutional avoidance, if there are two interpretations, and one interpretation is subject to serious constitutional doubt, the court should adopt the less dubious interpretation. In this case, classifying restitution under the MVRA as a criminal penalty would allow a court to avoid the difficult task of deciding whether the Seventh Amendment guarantees a right to a jury trial in determining a restitution order. Thus restitution should be construed as a criminal

199 Id at $178-79$.

200 Id at 179.

201 Id. Although the court did not explicitly reference a canon, it was in effect practicing constitutional avoidance by not deciding the issue unnecessarily.

202479 US 36 (1986).

203 Id at 53 n 14.

204 Id (emphasis added).

205 See Margaret Raymond, Note, The Unconstitutionality of the Victim and Witness Protection Act Under the Seventh Amendment, 84 Colum L Rev 1590, 1592 (1984) (arguing that "restitution under the VWPA is the equivalent of civil relief" and thus the defendant has a right to a jury); Bonnie Arnett Von Roeder, Note, The Right to a Jury Trial to Determine Restitution Under the Victim and Witness Protection Act of 1982, 63 Tex L Rev 671,691 (1984) (arguing that restitution under the VWPA is both civil in nature and a "'legal' remedy to which the right of jury trial attaches"). 
penalty, forcing courts to conclude that retroactive application of the MVRA violates the Ex Post Facto Clause. ${ }^{206}$

At first glance, it may appear that courts must also avoid labeling restitution as a criminal penalty to eliminate constitutional concerns under the Ex Post Facto Clause. However, a closer look proves that such an assumption is false. Under the civil interpretation, if it were decided that restitution was indeed a legal remedy and that the defendant had a right to a jury trial, then the MVRA would be unconstitutional. The entire statute would be invalidated and Congress would have to enact a new law that provided such a right. However, if restitution is labeled a criminal penalty, the MVRA is still constitutional despite the Ex Post Facto Clause. Although it is true that retroactive application of the MVRA would not be allowed under this interpretation, the statute itself would remain unchanged. Congress specifically stated that the MVRA would be effective, "to the extent constitutionally permissible ... for sentencing proceedings in cases in which the defendant is convicted on or after" April 24, 1996. ${ }^{207}$ So if a court determined that retroactive application of the MVRA would violate the Ex Post Facto Clause, then under Congress's command, the court would not be allowed to apply the MVRA retroactively. The Ex Post Facto Clause would only render certain applications of the statute unconstitutional, thereby preserving the MVRA.

\section{CONCLUSION}

Under the MVRA, Congress requires courts to award restitution to the victim from the criminal. Congress also specified that the effective date for the Act's implementation was the conviction date instead of the date of commission of the crime. This specification has forced some courts to consider whether application of the MVRA to a de-

206 Classifying restitution as criminal does not automatically bar retroactive application of the MVRA. As noted previously, the Supreme Court has stated in Weaver that the statute must constitute a substantive change. See notes 25-27 and accompanying text. However, since there has been no disagreement on this point on either side of the circuit split, it will be assumed for purposes of this Comment that the test in Weaver would be satisfied. See note 11. Interestingly, however, some unpublished cases have held the MVRA was not a substantive change in the law. Since these cases are unpublished, they do not carry substantial precedential weight. See United States $v$ Ledford, 1997 US App LEXIS 29167, *12-13 (6th Cir) (unpublished) (concluding that applying the MVRA did not result in an "increased order of restitution"); United States v Jackson, 1998 US App LEXIS 11645, *4 (6th Cir) (unpublished) (holding that "[u]nder the old statute, the district court was free to impose the same amount of restitution" and therefore, the penalty was not made more severe); United States v Braunstein, 1997 US App LEXIS 5548, *8 (2d $\mathrm{Cir}$ ) (unpublished) (noting that since the same result would be reached under the old statute and the amended version, the "punishment has not been enhanced").

207 Mandatory Victims Restitution Act $\$ 211,18$ USC $\S 2248$ note (effective date of 1996 amendments) (emphasis added). 
fendant who was convicted after the effective date but who committed the crime before that date violates the Ex Post Facto Clause.

This Comment has attempted to resolve the debate by examining the reasoning on both sides of the issue and demonstrating why the methods used heretofore could support either the civil or criminal view of the nature of restitution. Despite the equal plausibility of both interpretations, the classification of restitution has significant consequences. Many constitutional provisions are triggered by either a criminal or civil label. As this Comment has demonstrated, construing restitution under the MVRA as civil raises serious Seventh Amendment concerns. Because courts should avoid interpretations of statutes that create such constitutional difficulties, this Comment concludes that courts should consider restitution under the MVRA a criminal penalty. Therefore, courts should hold that retroactive application of the MVRA violates the Ex Post Facto Clause. 


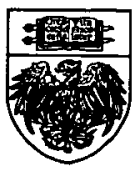

